\title{
AN EVALUATION OF THE INCOME TAX TREATMENT OF CLIENT LOYALTY PROGRAMME TRANSACTIONS BY SOUTH AFRICAN SUPPLIERS
}

\author{
Sophia Brink* \\ Stellenbosch University \\ sophiabrink@sun.ac.za
}

Received: May 2013

Accepted: March 2014

\begin{abstract}
The popularity of client loyalty programmes has increased drastically over the past few years, with more than 100 suppliers in South Africa currently making use of them. Despite the fact that client loyalty programmes have been prevalent in South Africa since the 1980s, the South African Revenue Service has issued no specific guidance on the income tax treatment of client loyalty programme transactions. The main objective of the research was to determine whether South African client loyalty programme suppliers treat client loyalty programme transactions correctly for income tax purposes. In order to meet this objective, available local and international literature were analysed to determine the proposed income tax treatment of a client loyalty programme transaction expenditure incurred by supplier for purposes of the client loyalty programme. The proposed correct income tax treatment was compared with a survey circulated to a population of client loyalty programme suppliers in South Africa. The comparison indicated that in practice the Income Tax Act No. 58 of 1962 is treated differently from the proposed treatment. This incorrect tax treatment could result in possible financial loss to the client loyalty programme supplier as taxpayer.
\end{abstract}

Keywords

Client loyalty programme, points, miles, supplier, deductibility of client loyalty programme expenditure

*Ms SM Brink is a senior lecturer in the School of Accountancy, Stellenbosch University, South Africa. 


\section{INTRODUCTION}

A client loyalty programme can be defined as a programme where consumers accumulate free points or miles based on the purchases of goods or services from a supplier (Brink \& Viviers, 2012:238). The consumer can exchange these points or miles for a variety of commodities (including goods, services or a discount on a next purchase transaction) at a supplier (Liu, 2007:20). The popularity of client loyalty programmes has increased drastically (Travel wires, 2011 ) and more than 100 suppliers in South Africa are already making use of these programmes (Conradie, 2011). Despite the fact that client loyalty programmes have been prevalent in South Africa since the 1980s (Travel wires, 2011), the South African Revenue Service (SARS) has issued no specific guidance on the income tax treatment of client loyalty programme transactions. Currently there is uncertainty about the correct income tax treatment of a client loyalty programme transaction in the hands of a South African supplier. Client loyalty programme expenditure meets all the requirements of section $11(a)$, namely expenditure or a loss not of a capital nature, actually incurred and in the production of income (for carrying on a trade) (Brink, 2011: 54-63). Therefore in practice client loyalty programme suppliers succeed in deducting the expenditure incurred in terms of section 11 (a). The uncertainty lies in the question whether the deduction is claimed in the correct year of assessment. This article is based on research done for an unpublished master's dissertation (Brink, 2011: 1-156).

The scope of literature regarding the tax treatment of client loyalty programme transactions in South Africa is limited. The existing literature regarding the tax treatment of client loyalty programme transactions in South Africa mainly focuses on the taxability of client loyalty programme benefits received in the hands of the consumer as a natural person. Pretorius (2010:1-71), Andoh (2008:1-80), Jones (2009:1-2) and Clegg (2002:33-35) investigated the taxability of points or miles earned by an employee based on goods or services purchased by their employers. Brink and Viviers's (2012:437) main objective was to investigate whether the existing provisions in the Income Tax Act No. 58 of 1962 (hereafter referred to as 'the Income Tax Act') and related case law provide a basis for taxing client loyalty programme benefits in the hands of the consumer as a natural person. From the above literature it was clear that there is still a gap in the investigation of the income tax treatment of client loyalty programme transactions in the hands of the supplier.

All references to 'section' in this article are to the sections of the Income Tax Act, unless the context indicates otherwise.

\section{RESEARCH OBJECTIVE, VALUE, DESIGN AND METHODOLOGY}

The main objective of the research was to determine whether South African client loyalty programme suppliers treat client loyalty programme transactions correctly for income tax purposes. It is important to interpret and apply the Income Tax Act correctly, because an incorrect tax treatment could result in possible financial loss to the client loyalty programme supplier as taxpayer or place an administrative burden on the taxpayer to open, correct and resubmit a previous year's income tax return if a deduction was claimed in an incorrect year of assessment. In conducting this study it was decided that only chief operator programmes would be focused on, as this was an initial study and the scope of the study would otherwise be too wide. Another reason for this decision was the fact that the information (specifically the membership numbers) regarding these programmes was readily available from Conradie's study 
(refer to section 4 Selection of client loyalty programmes for further investigation). A literature review was performed as suggested by Hofstee (2006:121), and was intended to produce a new perspective on the interpretation of section $11(a)$ in considering a client loyalty programme transaction. The literature review was also applied to understand the objectives of the study and to develop a questionnaire. A survey was used to obtain factual information (Hofstee, 2006:122) in order to do a comparative analysis (Hofstee, 2006:124).

In order to meet the main objective, the available local and international literature was analysed to determine what the proposed income tax treatment of a client loyalty programme transaction entails. The proposed income tax treatment was compared with the data obtained through a survey circulated to a population of client loyalty programme suppliers in South Africa.

The population consisted of 27 client loyalty programme suppliers (refer to section 4 Selection of client loyalty programmes for further investigation for the population selection criteria). The questionnaire was aimed at determining how client loyalty programme suppliers account for their client loyalty programme transactions for income tax purposes.

Due to the nature of this study, the way the questions were formulated was very important for meeting the objectives. The respondents had to find it easy to understand and answer the questions so that the desired results could be achieved. In order to eliminate all ambiguity, the questionnaire was given to several accountants for review, as people with accounting backgrounds would, in all likelihood, be the ones responsible for answering the questions. A qualified statistician who is a specialist in the use of questionnaires and the interpretation of data received from it reviewed the questionnaire to ensure that questions were properly formulated and that the data obtained from it would be relevant and feasible for this study. In order to identify the population for participation in the survey, information from a study on client loyalty programmes in South Africa by Conradie was used.

The questionnaire was circulated to this population of client loyalty programme suppliers and the respondents had three months to complete the questionnaire. The following follow-up procedures were followed to ensure an optimum response rate: all respondents were reminded to complete the questionnaire on a weekly basis. At the end of the three-month period all respondents who failed to complete the questionnaire were contacted telephonically. Of the 27 respondents, 10 valid responses were obtained, three declined to participate and the rest did not respond. These 10 respondents, constituting a response rate of $37 \%$, were deemed representative of client loyalty programme suppliers in South Africa. Confidentiality concerns were cited as the reason why three of the client loyalty programmes declined. The questionnaires were received and the data was processed.

The comparison indicated whether, and to what extent, South African client loyalty programme suppliers' tax treatment of client loyalty programme transactions is in line with the proposed treatment. A selection of the most popular client loyalty programmes in South Africa based on known active membership numbers was made in order to obtain a better understanding of the functioning of client loyalty programmes. The terms and conditions of these respective client loyalty programmes were analysed as further discussed under section 5 (Terms and conditions of client loyalty programmes). Taking into consideration the functioning of client loyalty programmes, the income tax treatment of client loyalty programme transactions in the hands of the supplier was analysed with reference to relevant income tax sections and judicature. 
In order to find income tax principles or practices that can be useful in a South African context, the income tax treatment of client loyalty programme transactions in South Africa was compared with that of a country with similar income tax legislation as South Africa. South African income tax legislation shows many similarities with that of Australia due to the fact that it originated from the New South Wales Act of 1895 (Australian Income Tax Legislation). Both South Africa and Australia are former British colonies, and a strong British influence is therefore present in the development of the income tax legislation of these countries (Willemse, 2010:38). In the search for principles and practices that can be useful in a South African context, it would be of value to investigate Australian income tax law.

Given the popularity of client loyalty programmes in South Africa, together with the extremely high rand value associated with them (Travel wires, 2011), it is important to correctly account for client loyalty programme transactions for income tax purposes.

In order to enforce compliance with the obligations imposed under a tax Act, the Tax Administration Act No. 28 of 2011 (hereafter referred to as 'the Tax Administration Act') provides for penalties to be imposed where a taxpayer failed to comply with a provision of a tax Act or understated his/her tax liability. Two types of penalties can be applicable for client loyalty programme suppliers' failure to comply with section 11(a) of the Income Tax Act namely 1) the percentage-based penalty and 2) the understatement penalty.

\subsection{Percentage-based penalty}

Section 213(1) of the Tax Administration Act states that where an amount of tax was not paid as and when required under a tax Act, SARS must, in addition to any other penalty or interest for which the person may be liable, impose a penalty equal to a percentage of the amount of unpaid tax as prescribed under the tax Act.

\subsection{Understatement penalty}

In the case of an understatement, the taxpayer has to pay, in addition to the tax payable, an understatement penalty determined in terms of an understatement penalty percentage table, unless the understatement results from a bona fide inadvertent error (section 222(1) of the Tax Administration Act).

Before investigating the income tax treatment of a client loyalty programme transaction it is important to obtain a better understanding of the functioning of these programmes.

\section{THE DEFINITIONS AND FUNCTIONING OF CLIENT LOYALTY PROGRAMMES}

Section 1 of the Consumer Protection Act No. 68 of 2008 defines the term 'loyalty' as follows:

'... any arrangement or scheme in the ordinary course of business, in terms of which a supplier of goods or services... offers or grants to a consumer any loyalty credit or award in connection with a transaction or an agreement ...'

The basic functioning of client loyalty programmes is as follows: Members of the general public can apply for membership by completing an application form where personal information is provided. Approved members will be issued with a membership card that should be scanned during each purchase transaction in order to accumulate client loyalty programme points or 
miles. A magnetic strip on the back of the membership card collects the details of the items purchased, together with the points or miles that are granted (Maharaj, 2008:12). The accumulated points or miles on the membership card may be exchanged for goods, services or a discount on goods or services in a later purchase transaction.

\section{SELECTION OF CLIENT LOYALTY PROGRAMMES FOR FURTHER INVESTIGATION}

Between 2003 and 2007 Conradie conducted comprehensive studies on client loyalty programmes in South Africa to assess the value that client loyalty programmes offer their members. The cash value (calculated as a percentage of cash back on actual expenditure), the variety of benefit choices and user-friendliness of client loyalty programmes were among the factors considered in order to determine this value (Conradie, 2007:12; Conradie \& Goldstuck, 2005:13; Conradie \& Goldstuck, 2003:8). Based on the report by Conradie (2007:1-283), a population of client loyalty programme suppliers for sampling was identified with reference to the following criteria: the client loyalty programme must be a technology-enabled chief operator programme, nationally available to the general public, launched before 1 March 2007 and must have purchase behaviour as incentive. Twenty-seven client loyalty programmes met these criteria and therefore represented the population.

The most popular client loyalty programmes based on known active membership numbers were selected from this population to form part of the sample. The population was stratified on the basis of the role that the programme owner plays and the type of industry sector in which the client loyalty programme finds itself. The selection was extended by selecting a further two client loyalty programmes to ensure that the sample was representative of all the different roles that the programme owner can play, as well as all industry sectors. TABLE 1 contains the seven selected client loyalty programmes, the active membership per programme, and the percentage of the total known active membership numbers. The selection ensured coverage of $78.9 \%$ of the population.

Given the percentage one can argue with a reasonable degree of confidence that it substantially represents the terms and conditions of client loyalty programmes in the South African market as discussed under section 5 below.

\section{TERMS AND CONDITIONS OF CLIENT LOYALTY PROGRAMMES}

The selected client loyalty programmes were examined in order to compare the similarities and differences between them regarding the value of points or miles awarded, and each programme's terms and conditions (Brink, 2011:31-52). This comparison was applied to categorise the client loyalty programmes for further investigation into the income tax treatment thereof. The most distinctive differences in the terms and conditions of client loyalty programmes in the various industries are expiry dates, the determinacy of the value of points or miles, the form in which points or miles are received (cash can be paid, a cash-back reward can be issued or points or miles can accumulate on the membership card), access to accumulated points or miles, and on whom the obligation to supply benefits rests (either on the supplier or on a third party). Where a third party supplies benefits the supplier who originally granted the 
points or miles will be responsible to compensate the third party in exchange for supplying the benefits.

TABLE 1: Selection of client loyalty programmes, active membership number per programme and the percentage of the total known active membership

\begin{tabular}{lcc}
\hline \multicolumn{1}{c}{ Client loyalty programmes selected } & $\begin{array}{c}\text { Active membership } \\
\text { number }\end{array}$ & $\begin{array}{c}\text { Percentage of the total } \\
\text { known active membership }\end{array}$ \\
\hline Clicks Club Card & 2100000 & $24.4 \%$ \\
eBucks & 1100000 & $12.8 \%$ \\
\hline Edgars Purple Cash Card & 1080000 & $12.5 \%$ \\
SAA Voyager & 890000 & $10.3 \%$ \\
Dis-Chem Benefit Programme & 750000 & $8.7 \%$ \\
Sun InternationalMostValued Guest & 505000 & $5.9 \%$ \\
Discovery Card Vitality & 374000 & $4.3 \%$ \\
\hline $\begin{array}{l}\text { Total known active membership of identified } \\
\text { client loyalty programmes }\end{array}$ & 8624400 & \\
Coverage & & $78.9 \%$ \\
\hline
\end{tabular}

Source: Conradie, 2007:135-235

The following different client loyalty programme categories exist:

- A client loyalty programme that pays out cash for accumulated points or miles

- A client loyalty programme that issues cash-back rewards for a predetermined number of accumulated points or miles, the cash-back rewards are subject to an expiry date and the consumer has an option to exchange the cash-back rewards issued only with the client loyalty programme

- A client loyalty programme that issues cash-back rewards for a predetermined number of accumulated points or miles, the cash-back rewards are subject to an expiry date and the consumer has an option to exchange the cash-back rewards issued, with the client loyalty programme or with a third party

- A client loyalty programme where points or miles accumulate on a membership card and the consumer has unlimited access to the points or miles, the points or miles are not subject to an expiry date and the consumer has an option to exchange the points or miles awarded only with the client loyalty programme

- A client loyalty programme where points or miles accumulate on a membership card and the consumer has unlimited access to the points or miles, the points or miles are not subject to an expiry date and the consumer has an option to exchange the points or miles awarded, with the client loyalty programme or with a third party

- Client loyalty programmes where points or miles accumulate on a membership card and the consumer has unlimited access to the points or miles, the points or miles are subject to an expiry date and the consumer has an option to exchange the points or miles awarded only with the client loyalty programme 
- A client loyalty programme where points or miles accumulate on a membership card and the consumer has unlimited access to the points or miles, the points or miles are subject to an expiry date and the consumer has an option to exchange the points or miles awarded with the client loyalty programme or with a third party

Each category of client loyalty programmes will have different income tax consequences based on the differences in their terms and conditions. Only three of the abovementioned categories responded, and the findings are discussed under section 8 Findings based on empirical study.

\title{
6. ANALYSIS OF SOUTH AFRICAN INCOME TAX LEGISLATION
}

Considering the functioning of client loyalty programmes as well as the terms and conditions of the selected client loyalty programmes, the income tax treatment by the supplier is analysed and discussed below. The supplier is referred to as the taxpayer.

As part of a client loyalty programme transaction the taxpayer grants points or miles. The consumer can exchange these points or miles at the taxpayer and/or at a third party. The taxpayer will incur an expense in supplying benefits (goods, services or a discount on the transaction) or in compensating the third party for supplying benefits.

In determining 'taxable income' all amounts allowed as deductions under the Income Tax Act must be deducted from 'income'. The 'income' referred to is income as defined in section 1 of the Income Tax Act, i.e. gross income minus all exempt income. The local courts have determined that section $11(\mathrm{a})$ and section $23(\mathrm{~g})$ of the Income Tax Act must be read together in order to determine whether an amount qualifies for a deduction, or not (Port Elizabeth Electric Tramway Co v CIR [1936] 8 SATC 13). A discussion of section 11(a) (positive test) and section 23( $\mathrm{g}$ ) (negative test) follows.

\subsection{Section 11(a) Positive test}

Section 11 of the Income Tax Act reads as follows:

\begin{abstract}
'For the purpose of determining the taxable income derived by any person from carrying on any trade, there shall be allowed as deductions from the income of such person so derived expenditure and losses actually incurred in the production of the income, provided such expenditure and losses are not of a capital nature ...'
\end{abstract}

A deduction will be granted only if all requirements of the definition are met. The following components of the definition are crucial in order to determine whether the points or miles granted will qualify for a deduction, and each must be considered individually, as discussed below.

\section{(a) Carrying on any trade}

Before any deductions under section 11 will be granted, the taxpayer must carry on a trade. Client loyalty programmes are used as a marketing strategy (Garcia G'omez, Guti'errez Arranz, Guti' errez \& Cilli' an, 2006: 387) within the carrying-on of a trade, and it is highly unlikely that a client loyalty programme will be implemented where a carrying-on of a trade is not present. All taxpayers who grant points or miles under a client loyalty programme are likely to meet the 'carrying on any trade' requirement. 


\section{(b) Expenditure and losses}

The word 'expenditure' is not limited to cash payments, but also includes payments in any form other than cash (CSARS $\vee$ Labat [2011] ZASCA 157). A taxpayer that pays a third party compensation for supplying benefits or supplies benefits (goods, services or discount) itself in terms of a client loyalty programme incurs an expenditure and meets the 'expenditure and loss' requirement.

\section{(c) Actually incurred}

Once the taxpayer pays the third-party compensation for supplying benefits or supplies benefits itself in exchange for points or miles or cash-back rewards, the expense will be actually incurred. In most cases, consumers will accumulate enough points or miles in a given year to qualify for a cash-back reward (Brink, 2011: 32-33). Where consumers exchange points or miles earned or cash-back rewards received in a given year, in that same year of assessment, it means that the 'actually incurred' requirement is met, because the taxpayer will pay the third-party compensation or will supply benefits itself. However, it is questionable whether a liability for the taxpayer will arise if consumers do not accumulate enough points or miles to qualify for a cashback reward in a given year, or if points or miles earned or cash-back rewards received during a given tax year are not exchanged for benefits in the same year of assessment.

In Caltex Oil (SA) Pty Ltd v SIR [1975] 37 SATC 1 it was determined that 'expenses actually incurred' does not mean expenditure actually paid during the year of assessment, but means 'all expenditure for which a liability has been incurred during the year, whether the liability has been discharged during that year or not'. In a client loyalty programme transaction a liability will arise in the hands of the taxpayer. It is uncertain exactly when the obligation arises. To address these uncertainties the three different forms in which points or miles are awarded are considered. Points or miles can be granted in three different forms, namely: cash that is paid, cash-back rewards that are issued, or points or miles that are accumulated on a membership card. Each of these forms will now be considered separately.

\section{Cash paid to consumer}

For client loyalty programmes that pay cash for accumulated points or miles, the liability for the taxpayer to supply benefits (to pay cash) arises when the points or miles are granted. No requirement is provided that a certain amount of points or miles be accumulated before the consumer qualifies for a cash payment, but the consumer will have to wait for the monthly payout date before the benefit will be obtained (Discovery credit card and Vitality) (Discovery, 2011).

\section{Cash-back reward issued to consumer}

For client loyalty programmes that issue cash-back rewards a predetermined number of accumulated points or miles are required before the consumer qualifies for a cash-back reward. Consequently, consumers have limited access to accumulated points or miles and an obligation in the hands of the taxpayer will occur only when a cash-back reward is issued (Edgars Purple Cash Card) (Edgars, 2011). 


\section{Points or miles that accumulate on the membership card}

For client loyalty programmes where points or miles accumulate on membership cards, the consumer has free access to use these points or miles at any given time. Three different client loyalty programmes exist where points or miles accumulate on membership cards:

- The consumer can exchange points or miles only with a third party.

- The consumer can exchange points or miles only with the taxpayer.

- The consumer has the option to exchange points or miles with the taxpayer or with a third party.

The selection of client loyalty programmes is limited to chief programme operators (refer to section 4 Selection of client loyalty programmes for further investigation). The chief programme operator of a client loyalty programme acts as the facilitator of the client loyalty programme. Some entities provide participation in a client loyalty programme in which the said entity itself is not the chief programme operator of the client loyalty programme (Conradie, 2007:13). A client loyalty programme where the consumer can exchange points or miles or cash-back rewards only with a third party will not be the chief programme operator of the programme and is therefore excluded from the scope of this article.

For client loyalty programmes where the consumer can exchange points or miles only with the taxpayer and no required minimum accumulated points or miles exist (for example Dis-Chem Benefit Programme) (Dis-Chem customer care line, 2011), the taxpayer's obligation to supply benefits will arise when granting points or miles or when issuing cash-back rewards and not during the eventual exchange thereof. If points or miles are granted or cash-back rewards are issued during a year of assessment, it means in effect that the taxpayer actually incurred the expenditure in that year of assessment, whether the benefits were supplied in that year, or not (applying the principles from Caltex Oil (SA) Pty Ltd v SIR [1975] 37 SATC 1, Concentra (Pty) Ltd v CIR [1942] 12 SATC 95 and Baikie v CIR [1931] 5 SATC 193).

For client loyalty programmes where the consumer has an option to exchange points or miles or cash-back rewards with the taxpayer or with a third party (for example SAA Voyager miles earned may be exchanged with SAA or any of SAA's programme partners) (South African Airways customer care line, 2011), the same principle as in the case of client loyalty programmes where the consumer can exchange points or miles only with the taxpayer applies. Even though the value of the expenditure is only determinable on the day the points or miles or cash-back rewards are exchanged, the obligation still arises on the day the points or miles are granted or when the cash-back reward is issued. Refer to section 6.4 Ascertainable amount for a discussion of circumstances where the amount of the deduction is unquantifiable at the last day of the year of assessment during which it is incurred.

The situation may occur where the taxpayer has no further obligation at the end of the year of assessment in respect of points or miles or cash-back rewards that were previously granted or issued. The following examples are relevant and will be considered in more detail:

- Client loyalty programmes where the points or miles are not subject to an expiry date and the consumer fails to exchange the points or miles for benefits (for example a consumer loses his or her cash-back reward)

- Client loyalty programmes where the points or miles are subject to an expiry date and the consumer fails to exchange the points or miles earned in time (before the expiry date) 
- Client loyalty programmes where a cash-back reward is issued and the consumer fails to exchange the cash-back reward received in time, in other words before the expiry date. (In all client loyalty programmes investigated where a cash-back reward is issued, the cashback reward is subject to an expiry date.)

Points or miles not subject to an expiry date: Consumer fails to exchange points or miles

The possibility exists that points or miles granted will never be exchanged. For client loyalty programmes where the consumer can exchange points or miles with the taxpayer only or with the taxpayer or with a third party, the expenditure is incurred when points or miles are granted. It is impossible for the taxpayer to determine whether the consumer will exchange points or miles, or not. The taxpayer will always have an obligation to supply benefits in terms of points or miles that were previously granted and will meet the requirement 'actually incurred' when points or miles are granted.

Points or miles subject to an expiry date: Consumer fails to exchange points or miles in time (before the expiry date)

For client loyalty programmes where the consumer can exchange points or miles with the taxpayer only or with the taxpayer or with a third party and the consumer fails to exchange the points or miles earned in time (before the expiry date), the taxpayer will have no further obligation to supply benefits to the consumer or to pay compensation to a third party after the expiry date. At the end of the year of assessment, the taxpayer will, with reference to expired points or miles, be able to determine whether a liability exists, or not. Points or miles granted will no longer meet the 'actually incurred' requirement after the expiry date.

Cash-back reward subject to an expiry date: Consumer fails to exchange cash-back reward in time (before the expiry date)

The same principle as in the case of points or miles subject to an expiry date and the consumer fails to exchange points or miles in time (before the expiry date) applies here (refer to discussion above: Points or miles subject to an expiry date: Consumer fails to exchange points or miles in time (before the expiry date)).

\section{(d) In the production of income}

In order to qualify for a deduction against income, expenses and losses must actually be incurred in the production of income. A client loyalty programme is a marketing strategy aimed at encouraging consumer loyalty. Granting of points or miles or issuing cash-back rewards is the action being performed that leads to the expenditure (to pay the third-party compensation or to supply benefits themselves) and is closely related to the income-producing activities (in the form of repeated clientele) (applying the principle from Port Elizabeth Electric Tramway Co v CIR [1936] 8 SATC 13). Therefore a taxpayer supplying benefits in terms of a client loyalty programme or a taxpayer paying compensation to a third party for supplying benefits on its behalf will meet 'the production of income' requirement.

\section{(e) Not of a capital nature}

Section 11 (a) also requires that the expenditure or losses should not be of a capital nature. It is often difficult to distinguish between expenditure that is capital in nature and expenditure that is income in nature. In New State Areas Ltd v CIR [1946] 14 SATC 155 it was held that in 
determining whether the amount is of a capital nature, or not, it must be determined whether the expenditure incurred was part of the cost of performing the income-earning operations or as part of the cost of establishing or improving or adding to the income-earning structure (enduring benefit). Floating capital expenditure represents expenditure deductible in terms of section $11(a)$ and fixed capital expenditure represents capital expenditure, the deduction of which is prohibited under section 11(a) (Stiglingh, Koekemoer, Van Schalkwyk, Wilcocks \& De Swardt, 2013:143).

Expenses incurred to grant points or miles and/or to issue cash-back rewards and finally to supply benefits or to pay compensation to a third party indicate the expenditure to maintain a client loyalty programme. This expenditure is an expense caused by the income-earning operations and indicates floating capital expenditure not of a capital nature. Client loyalty programme expenditure is regarded as a marketing expense (Gilbert, 1996:575), which also supports the conclusion above. Therefore, the taxpayer that supplies benefits in terms of a client loyalty programme or pays compensation to a third party will meet the 'not of a capital nature' requirement.

Client loyalty programme expenditure in most cases should meet all the requirements of section 11 (a) (except for points or miles granted or cash-back rewards issued where the expiry date has lapsed without the exchange of the points or miles or cash-back rewards) (refer to (c) Actually incurred). Although an expense is deductible under section $11(a)$, the expenditure must pass the negative test under the general deduction formula.

\subsection{Section 23(g): Negative test}

Section 23 contains a list of items that may be claimed as a deduction. Section 23 and section $23(\mathrm{~g})$ of the Income Tax Act read as follows:

'No deductions shall in any case be made in respect of the following matters, namely -

(g) any moneys, claimed as a deduction from income derived from trade, to the extent to which such moneys were not laid out or expended for the purposes of trade.'

Client loyalty programmes seek to bind consumers to an entity by offering rewards to ensure sustained goodwill (Kivetz \& Simonson, 2002:156) and are utilised in an effort to attract and retain consumers (Mcllroy \& Barnett, 2000:347) to increase revenue and eventually profits (Butcher, 2002:39). Client loyalty programme expenditure incurred to grant points or miles and/or to issue cash-back rewards and finally to supply benefits or pay compensation to a third party will therefore be incurred for business purposes and will pass the negative test of section $23(\mathrm{~g})$. Therefore, client loyalty programme expenditure meets all the requirements of section $11(\mathrm{a})$ and section $23(\mathrm{~g})$.

To further support the above conclusion reference can be made to the income tax treatment of the consumer receiving client loyalty programme benefits. According to income tax principles, in most cases if one taxpayer recognises an amount as gross income the other taxpayer will be entitled to a deduction. Brink and Viviers (2012:454) conclude that points or miles received by a consumer meet all the requirements of the 'gross income' definition and as a result should be taxable. If the consumer should be taxed on the benefits received, the supplier will succeed in deducting the expenditure incurred.

It must be determined what the tax treatment would be if a deduction is claimed during year one (in terms of points or miles granted or cash-back rewards issued subject to an expiry date) and 
during year two when the expiry date lapsed without the exchange of the points or miles or cashback rewards. A discussion of this matter follows, as a possible recoupment may arise.

\subsection{Recoupment}

Section 8(4) (a) of the Income Tax Act reads as follows:

'There shall be included in the taxpayer's income all amounts allowed to be deducted or set off under the provisions of sections 11 to $20 \ldots$ whether in the current or any previous year of assessment which have been recovered or recouped during the current year of assessment ...'

For client loyalty programmes, if a deduction is claimed during year one in respect of points or miles granted or cash-back rewards issued subject to an expiry date, and if during year two the expiry date lapsed without the consumer exchanging the points or miles or cash-back rewards, it means in effect that the taxpayer was previously entitled to a deduction in respect of an expenditure that it never actually incurred. Accordingly, in year one the taxpayer's taxable income will be less because of the deduction granted. The fact that no expenditure was actually incurred in respect of a deduction already allowed during year one will result in a recovery. With the lapsing of the expiry date the value of the points or miles or cash-back rewards must be included in the taxpayer's gross income.

\subsection{Ascertainable amount}

If an expenditure or a loss is not of a capital nature, actually incurred and in the production of income (for carrying on a trade), the taxpayer qualifies for a section 11 (a) deduction. To claim the amount as a deduction the value of the amount must be ascertainable. An expenditure incurred by a taxpayer qualifying for a deduction in terms of section 11(a) may in some circumstances be unquantified as at the last day of the year of assessment during which it is incurred, in the sense that although incurred the quantum of the expenditure can be determined only in a subsequent year of assessment (Williams, 2009:438). The liability to pay an expenditure in a year of assessment subsequent to the one in which the expenditure was incurred may in the subsequent year be reduced, waived or otherwise be extinguished without actual payment (Williams, 2009:438).

For client loyalty programmes that pay cash directly into the consumer's account for accumulated points or miles, the value of the expenditure will amount to the rand value linked to the points or miles.

For client loyalty programmes where a cash-back reward is issued for accumulated points or miles, the value of the expenditure will amount to the value stipulated on the cash-back reward.

For client loyalty programmes where points or miles accumulate on a membership card, two scenarios arise, namely:

\section{- Value determinable when points or miles are granted}

The points or miles of all client loyalty programmes that were investigated, except SAA Voyager miles, have a determinable value. The value of the expenditure will amount to the rand value linked to the points or miles. 


\section{- Value only determinable when points or miles are exchanged}

An SAA Voyager member has an option to exchange SAA Voyager miles with SAA or with any of the programme partners (third parties) for benefits. Accumulated SAA Voyager miles can thus be exchanged for flights, car rental, leisure and lifestyle benefits (South African Airways, 2011). Spending rates for the use of miles for each of the benefits are applicable and the value per mile will differ from the type of benefit ultimately obtained. The specific rand value per mile cannot be determined when miles are granted, since the value depends on how it is used or the choice of the type of benefit that will be obtained. SAA's obligation to supply benefits or to pay a third party compensation arises when the points or miles are granted. Even though the value of the expense incurred is not ascertainable, the expense is actually incurred and therefore deductible (COT V 'A' Company [1979] 41 SATC 59). A possible solution or suggestion for determining the value of the miles granted is as follows: The value per mile may be determined with reference to the Mileage Purchase Option's value per mile. A SAA Voyager member can use the Mileage Purchase Option when the member's accumulated miles are inadequate for a specific benefit. The member may purchase up to $50 \%$ of the miles required for a specific benefit at R2 500 per 1000 miles. Miles are sold only in multiples of 1000 (South African Airways, 2011). Based on this a rand value per mile can be calculated as R2,50 and therefore it is possible to determine the value per mile.

For all client loyalty programmes that were investigated, the value of the expenditure is ascertainable on the date that the taxpayer qualifies for a section $11(a)$ deduction. The taxpayer will therefore be able to claim the expenditure incurred.

In order to evaluate the above conclusion, the income tax treatment of client loyalty programme transactions in South Africa can be compared with that of Australia.

\section{COMPARING SOUTH AFRICAN INCOME TAX TREATMENT WITH AUSTRALIAN INCOME TAX TREATMENT}

The deductibility of client loyalty programme expenditure lies in the general deduction formula in section 8-1 of the Income Tax Assessment Act 1997 (hereafter referred to as 'ITAA 1997'). Section 8-1 of the ITAA 1997 provides for a deduction from your assessable income any loss or outgoing to the extent that it is incurred in gaining or producing your assessable income or it is necessarily incurred in carrying on a business for the purpose of gaining or producing your assessable income. The wording of section 8-1 of the ITAA 1997 is similar to that found in section 11 (a) of the Income Tax Act. 'Loss or outgoing' is similar to 'expenditure and losses', 'incurred' is similar to 'actually incurred' and 'gaining or producing your assessable income ... in carrying on a business' is similar to 'in the production of income'.

The Australian Taxation Office issued specific guidance on the deductibility of client loyalty programme expenditure in Taxation Determination 2003/20 (hereafter referred to as 'TD $2003 / 20^{\prime}$ ). TD $2003 / 20$ states that a loss or outgoing must have been incurred to qualify for a deduction. For a loss or outgoing to be incurred there needs to be a presently existing liability of a pecuniary character (Nilsen Development Laboratories Pty v FC of T 144 CLR 616 at 624). This principle corresponds to the South African principle that 'expenses actually incurred' does not mean expenditure actually paid during the year of assessment, but means 'all expenditure for which a liability has been incurred during the year, whether the liability has been discharged during that year or not' (Caltex Oil (SA) Pty Ltd v SIR [1975] 37 SATC 1). 
However, the Australian interpretation of the word 'incurred' goes on to say that for an expense to be deductible, the liability must be 'more than impending, threatened or expected' (New Zealand Flax Investments Ltd v FC of T [1938] 61 CLR 179 at 207). TD 2003/20 states that when the points are granted to the consumer the supplier has not completely subjected itself to the future liability, as the liability is subject to contingencies, as an actual entitlement to a benefit may not arise until a certain number of points are accrued. Even at that time there is no certainty that the points will be exchanged for benefits. The liability will arise only when the points are exchanged for benefits. Based on TD 2003/20 the expenditure will only be deductible once the consumer exchanges the points and the supplier supplies the benefits.

This second principle is, however, not applied in South Africa. It cannot be argued that the mere possibility of a taxpayer not settling a liability means that the taxpayer is not unconditionally liable (Clegg \& Stretch, 2012: par 10.2.5). If this principle were correct no accrual of expenditure for tax purposes could take place prior to payment, since a debt, for example, can in theory always be waived prior to payment (Clegg \& Stretch, 2012: par 10.2.5). The mere theoretical possibility that a consumer does not return to exchange points for benefits cannot be used to conclude that the amount is not unconditionally due. The only South African income tax principle that is aligned with the abovementioned Australian principle is that the liability must be unconditional (CIR v Golden Dumps (Pty) Ltd [1993] 55 SATC 198, Edgars Stores Ltd v CIR [1988] 50 SATC 81). At the time the points or miles are granted or the cash-back rewards are issued, all conditions are met; the consumer need not buy any other goods, as he is already unconditionally entitled to the benefits.

It can be concluded that although the wording of section 8-1 of the ITAA 1997 seems similar to that found in section $11(a)$ of the Income Tax Act the interpretation and therefore the application of the words contained in the sections differ. An income tax practice that South Africa can learn from the Australian Taxation Office is to issue specific guidance on the deductibility of client loyalty programme expenditure to ensure correct and consistent interpretation and application of legislation and to eliminate any uncertainties.

In order to address the main objective of the article, the proposed income tax treatment can be compared with responses to a questionnaire circulated to a population of client loyalty programme suppliers in South Africa. The proposed income tax treatment can be summarised as follows:

It was found that for client loyalty programmes where the points or miles or cash-back rewards are not subject to an expiry date, the expenditure incurred will be deductible under section 11 (a) once the points or miles are granted or the cash-back rewards are issued. At this stage all the requirements of section $11(\mathrm{a})$ and section 23(g) of the Income Tax Act are met and the value of the expenditure is ascertainable.

For client loyalty programmes where the points or miles or cash-back rewards are subject to an expiry date, the expenditure incurred will be deductible under section $11(a)$ at the end of the year of assessment only if the expiry date has not lapsed. At this stage all the requirements of section 11 (a) and section 23( $\mathrm{g}$ ) of the Income Tax Act are met and the value of the expenditure is ascertainable.

For client loyalty programmes, if a deduction is claimed during year one in respect of points or miles granted or cash-back rewards issued subject to an expiry date, and in year two the expiry date lapses without the consumer exchanging the points or miles or cash-back rewards, then the 
taxpayer must include the value of those points or miles or cash-back rewards in gross income (in terms of special inclusion paragraph (n)).

\section{FINDINGS BASED ON EMPIRICAL STUDY}

The responses provided in the questionnaires indicated how client loyalty programme suppliers account for a client loyalty programme transaction for income tax purposes.

\subsection{Respondent profile}

From the total population of 27 suppliers, 10 responses were obtained, constituting a response rate of $37 \%$. Three different client loyalty programme suppliers categories responded, and the description as well as the number of respondents per category are presented in TABLE 2.

\section{TABLE 2: Description of client loyalty programme and corresponding number of respondents}

\begin{tabular}{|c|c|c|}
\hline Category & Description & $\begin{array}{l}\text { Number of } \\
\text { respondents }\end{array}$ \\
\hline 1 & $\begin{array}{l}\text { A client loyalty programme where points or miles accumulate on a } \\
\text { membership card, the points or miles are not subject to an expiry } \\
\text { date, the consumer has an option to exchange the points or miles } \\
\text { awarded only with the client loyalty programme and no required } \\
\text { minimum accumulated points or miles exist. }\end{array}$ & 4 \\
\hline 2 & $\begin{array}{l}\text { A client loyalty programme where points or miles accumulate on a } \\
\text { membership card, the points or miles are subject to an expiry } \\
\text { date, the consumer has an option to exchange the points or miles } \\
\text { awarded only with the client loyalty programme and no required } \\
\text { minimum accumulated points or miles exist. }\end{array}$ & 5 \\
\hline 3 & $\begin{array}{l}\text { A client loyalty programme where points or miles accumulate on a } \\
\text { membership card, the points or miles are subject to an expiry } \\
\text { date and the consumer has an option to exchange the points or } \\
\text { miles awarded with the client loyalty programme or with a third } \\
\text { party and a required minimum point or miles exist. }\end{array}$ & 1 \\
\hline
\end{tabular}

Source: Author's analysis

\section{Income tax treatment of a client loyalty programme transaction}

Different questions on various types of income tax treatment were applicable for the different client loyalty programme categories. A discussion of the results per category follows.

\section{Category 1}

Respondents were required to indicate how they account for a client loyalty programme transaction for income tax purposes. The results are summarised in TABLE 3 . 
TABLE 3: Income tax treatment of a client loyalty programme transaction for category 1 client loyalty programmes

\begin{tabular}{lc} 
Income tax treatment of a client loyalty programme transaction & Response \\
\hline a) A section $11(a)$ deduction is claimed when the points or miles are & $0 \%$ \\
awarded (at the value of the points or miles awarded). & $100 \%$ \\
b) A section $11(a)$ deduction is claimed when the consumer exchanges the & \\
points or miles for goods, services or discount (benefits) (at the value of & \\
points or miles exchanged or the benefits supplied). & $0 \%$ \\
c) No income tax implications arise.
\end{tabular}

Source: Author's analysis

The proposed tax treatment, based on the Act, is reflected in (a). All the respondents indicated that the manner in which they treat the client loyalty programme transaction for tax purposes is reflected in (b).

It is clear from the above response that in practice the Income Tax Act could not be interpreted correctly. In most cases points or miles awarded in a year of assessment will be exchanged for benefits in the same year of assessment. In this scenario the above erroneous interpretation of the Income Tax Act does not lead to an incorrect tax calculation by the taxpayer for those specific points or miles. If points or miles awarded in a year of assessment are exchanged for benefits in the same year of assessment the section 11 (a) deduction will be claimed in that year whether the Income Tax Act is correctly interpreted or not. However, it is possible that points or miles awarded in a year of assessment will not be exchanged for benefits in that same year of assessment. The result of this erroneous interpretation of the Income Tax Act is that the section 11 (a) deduction will not be claimed in the year of assessment the expenditure is 'actually incurred'. In Concentra (Pty) Ltd v CIR [1942] 12 SATC 95 it was held that deductible expenditure is restricted to that incurred in the year of assessment. The general rule is that no expenditure incurred in a particular year of assessment may be deducted in subsequent years of assessment. It is therefore crucial that the taxpayer claim the section 11 (a) deduction once the expenditure is 'actually incurred' to prevent possible financial loss.

\section{Category 2 and 3}

Respondents were required to indicate how they account for a client loyalty programme transaction for income tax purposes. The results are summarised in TABLE 4.

The proposed tax treatment, based on the Act, is reflected in (c). All of the respondents indicated that the correct income tax treatment of a client loyalty programme transaction is reflected in (b). 
TABLE 4: Income tax treatment of a client loyalty programme transaction for category 2 and 3 client loyalty programmes

\begin{tabular}{lc}
\hline \multicolumn{1}{c}{ Income tax treatment of a client loyalty programme transaction } & Response \\
\hline a) A section 11 (a) deduction is claimed when the points or miles are awarded & $0 \%$ \\
(at the value of the points or miles awarded). & $100 \%$ \\
b) A section 11 (a) deduction is claimed when the consumer exchanges the \\
points or miles in time (before the expiry date) for goods, services or \\
discount (benefits) (at the value of points or miles exchanged or the \\
benefits supplied). \\
c) A section 11 (a) deduction is claimed at the end of the year of assessment \\
only for points or miles where the expiry date has not lapsed (at the \\
value of these points or miles). \\
d) No income tax implications arise.
\end{tabular}

Source: Author's analysis

The respondents were also required to indicate what the income tax treatment will be if a section 11 (a) deduction is claimed in one year of assessment in respect of points or miles awarded and the expiry date lapses in the next year of assessment, without the consumer exchanging the points or miles. The results are summarised in TABLE 5.

\section{TABLE 5: Income tax treatment of expired points or miles over two years of assessment for category 2 client loyalty programmes}

$$
\text { Income tax treatment of a client loyalty programme transaction }
$$

a) The value of the points or miles or cash-back reward will be included in gross income with the expiry of the due date (section $8(4)(a)$ recovery).

b) No income tax implications arise.

Source: Author's analysis

The proposed tax treatment, based on the Act, is reflected in (a). All of the respondents indicated that the correct income tax treatment of the above scenario is reflected in (a).

The above response indicates that these client loyalty programme suppliers understand the working of section $8(4)(a)$ in the context of a client loyalty programme transaction. These client loyalty programme suppliers however indicated that they claim the section 11 (a) deduction when the consumer exchanges the points or miles in time (before the expiry date) and therefore there will never be a recoupment from their point of view.

The above erroneous interpretation of the Income Tax Act (as reflected in TABLE 4) will have the same effect as discussed in the category 1 client loyalty programme. 


\section{CONCLUSION AND RECOMMENDATIONS}

It is clear from the survey that, in practice, the Income Tax Act could sometimes be interpreted incorrectly. The result of this erroneous interpretation of the Income Tax Act is that the section 11 (a) deduction will not be claimed in the year of assessment the expenditure is 'actually incurred'. If the taxpayer does not claim the section 11 (a) deduction in the correct year of assessment the claim can be lost forever, resulting in financial loss for the taxpayer (Concentra (Pty) Ltd v CIR [1942] 12 SATC 95). The alternative is for the taxpayer to open, correct and resubmit a previous year's income tax return. If a client loyalty programme supplier incorrectly interprets and applies the Income Tax Act it might lead to an understatement of its total income tax liability, and penalties might follow.

Given the results of the research conducted, the general conclusion is that there are gaps in the interpretation and application of the Income Tax Act in respect of client loyalty programme transactions. There is also a lack of guidance from the South African Revenue Service (SARS) regarding the tax treatment of client loyalty programme transactions that requires urgent attention.

It is recommended that to ensure correct and consistent interpretation and application of the Income Tax Act, the South African Revenue Service (SARS) should formulate guidelines regarding the tax treatment of client loyalty programme transactions in the hands of the supplier (the taxpayer granting points or miles to consumers).

This article highlights important principles that might contribute to the body of knowledge to prepare guidelines on the tax treatment of client loyalty programme transactions in the hands of the supplier. This information could be of use to role players in the South African tax environment.

\section{LIST OF REFERENCES}

Andoh, C. (2008). Business-financed employee voyager-mile points earned from SAA-a taxable benefit? Unpublished master's dissertation. Pretoria: University of Pretoria.

Australian Government (2003). Taxation Ruling TR 2003/20 [0nline]. Available at: http://law.ato.gov.au/atolaw/view.htm?docid=TXD/TD200320/NAT/AT0/00001. [Accessed: 14 June 2012].

Baikie v CIR [1931], 5 SATC 193, AD 496

Brink, S.M. (2011). Belasbaarheid van kliëntelojaliteitsprogramtransaksies in Suid-Afrika. Unpublished master's dissertation. Stellenbosch: Stellenbosch University.

Brink, SM. \& Viviers, H. (2012). Inkomstebelastinghantering van kliëntelojaliteitsprogramtransaksies in Suid-Afrika. Journal of Economic and Financial Sciences, 5(2), pp. 437-458.

Butcher, S. (2002). Customer Loyalty Programmes and Clubs [Online]. Available: http://books.google.co.za/books?id=VTkuUbNpNAPC\&pg=PA93\&lpg=PA93\&dq=aim+of+client+loyalty

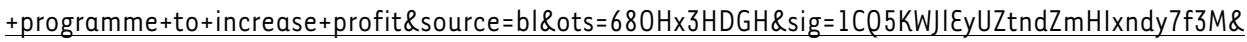

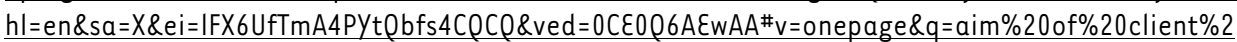
0loyalty\%20programme $\% 20$ to $\% 20$ increase $\% 20$ profit\&f=falsem. [Accessed: l August 2013 ]. 
Caltex Oil (SA) Pty Ltd v SIR [1975], 37 SATC 1, (1) SA 665 (A)

CIR v Golden Dumps (Pty) Ltd [1993], 55 SATC 198, (4) SA 110 (A)

Clegg, D. (2002). Voyager miles - taxable fringe benefit? Tax Planning: Corporate and Personal, 16(2), pp. 33-35.

Clegg, D. \& Stretch, R. (2012). The general deduction formula. Income Tax in South Africa. [Online]. Available at:

http://www.lib.sun.ac.za.ez.sun.ac.za/nxt/gateway.dll?f=templates $\$ f n=D e f a u l t . h t m \$ v i d=m y l n b: 10$. 1048/enu. [Accessed 14 June 2012].

Concentra (Pty) Ltd v CIR [1942], 12 SATC 95, CPD 508

Conradie, B. (bruce@worldwideworx.com). 17 June 2011. RE: Bruce Conradie. Email to author.

Conradie, B. (2007). Value in loyalty programmes 2007: A survey of South African rewards-based loyalty programmes. Razor's Edge Business Intelligence.

Conradie, B. \& Goldstuck, A. (2005. Value in loyalty programmes 2005: A survey of South African rewards-based loyalty programmes. Razor's Edge Business Intelligence World Wide Worx.

Conradie, B. \& Goldstuck, A. (2003). Value in loyalty programmes 2003: A survey of South African rewards-based loyalty programmes. Razor's Edge Business Intelligence World Wide Worx.

COTV 'A' Company [1979], 41 SATC 59,SA 738 (ZA)

Dis-Chem customer care line. (2011). Personal telephone interview. 26 January, Johannesburg.

Discovery (2011). Shop and save. [Online]. Available at:

http://www.discovery.co.za/portal/loggedout-individual/shop-save-card. [Accessed 27 January 2011].

Edgars (2011). Purple Cash Card. [Online]. Available at:

http://www.edgars.co.za/edgars/accounts/purple_card.htm. [Accessed 5 May 2011].

Edgars Stores Ltd v CIR [1988], 50 SATC 81, (3) SA 876 (A).

Garcia G'omez, B., Guti' errez Arranz, A. \& Guti'errez Cilli'an, J. (2006). The role of loyalty programs in behavioural and affective loyalty. Journal of Consumer Marketing, 23(7), pp. 387-396.

Gilbert, D.C. (1996). Relationship marketing and airline loyalty schemes. Tourism Management Journal, 17(8), pp. 575-582.

Hofstee, દ. (2006). Constructing a good dissertation. Johannesburg: દPદ.

Income Tax Assessment Act 1997 Act No. 38 of 1997 of Australia as amended.

Jones, S. (2009). Taxing frequent-flyer miles. TaxBreaksNewsletter, 285(10), pp. 1-2. [Online]

Available at: http://search.sabinet.co.za.ez.sun.ac.za/WebZ/images/ejour/

montb/montb_n285_al.pdf?sessionid=01-59014-263192708\&format=F. [16 July 2010].

Kivets, R. \& Simonson, I. (2002). Earning the right to indulge: effort as a determinant of customer preferences towards frequently programme rewards. Journal of Marketing Research, 39(2), pp. 155 170.

Liu, Y. 2007. The long-term impact of loyalty programmes on consumer purchase behaviour and loyalty. Journal of Marketing. [Online]. Available at:

http://web.ebscohost.com.ez.sun.ac.za/ehost/pdfviewer/pdfviewer?sid=eb91de90-b5da-4e0fbb71-4a9965cla313\%40sessionmgr11\&vid=5\&hid=17. [Accessed 19 April 2011]. 
Mcllroy, A. \& Barnett, S. (2000). Building customer relationships: do discount cards work? Managing Service, 10(6), pp. 347-355.

Maharaj, A. (2008). Awareness perceptions and effects of customer loyalty programmes within the retail sector of the Durban Metropolitan area. Unpublished master's dissertation. South Africa: South Africa University.

New State Areas Ltd v CIR [1946], 14 SATC 155, AD 610

New Zealand Flax Investments Ltd v FC of T[1938], 61 CLR 179

Nilsen Development Laboratories Pty v FC of T, 144 CLR 616

Port Elizabeth Electric Tramway Co v CIR [1936], 8 SATC 13, CPD 241

Pretorius, L. (2010). An analysis of the employees' tax implications of loyalty points awarded to employees in South Africa. Unpublished master's dissertation. Pretoria: Pretoria University.

Republic of South Africa. 1962. Income Tax Act No.58 of 1962. Pretoria: Government Printer.

Republic of South Africa. 2008. Consumer Protection Act No.68 van 2008. Cape town: Gazette 526 (32186):1-94.

Republic of South Africa. 2011. Tax Administration Act No. 28 of 2011. Cape Town: Gazette 565 (35491) 1-385.

CSARS v Labat, (669/10), [2011], ZASCA 157

South African Airways (2011). Terms and Conditions. [Online]. Available at:

https://www.flysaa.com/Journeys/cms/ZA/voyager/AboutVoyager/flysaa_VoyagerTermsAndConditi ons.html. [26 January 2011].

South African Airways customer care line. 2011. Personal telephone interview. 30 May, Johannesburg.

Stiglingh, M., Koekemoer, A.D., Van Schalkwyk, L., Wilcocks, J.S. \& De Swardt, R.D. (2013). SILKE: SuidAfrikaanse Inkomstebelasting 2012. Durban: LexisNexis.

Travel wires (2011). Terms and conditions distort loyalty programmes - Protea Hospitality. [Online]. Available at: http://www.travelwires.com/wp/2011/03/\%ع2\%80\%9Cterms-conditions\%ع2\%80\%9Ddistort/. [Accessed 8 April 2011].

Williams, R.C. (2009). Income tax in South Africa Cases and Materials. Durban: LexisNexis.

Willemse, L.C. (2010). Die inkomstebelastinghantering van franchisefooie in die Suid-Afrikaanse petroleumbedryf. Unpublished master's dissertation. Stellenbosch: Stellenbosch University. 